\title{
Seasonal and Basinal Influences on the Formation and Transport of Dissolved Trace Metal Forms in a Mining-Impacted Riverine Environment
}

\author{
Jeff B. Langman ${ }^{1, *}$, Kathleen Torso ${ }^{2}$ and James G. Moberly ${ }^{3}$ \\ 1 Department of Geological Sciences, University of Idaho, Moscow, ID 83844, USA \\ 2 Water Resources Program, University of Idaho, Moscow, ID 83844, USA; tors4488@vandals.uidaho.edu \\ 3 Department of Chemical and Materials Engineering, University of Idaho, Moscow, ID 83844, USA; \\ jgmoberly@uidaho.edu \\ * Correspondence: jlangman@uidaho.edu; Tel.: +1-208-885-0310
}

Received: 24 May 2018; Accepted: 24 July 2018; Published: 25 July 2018

\begin{abstract}
The release of nanophase metal particles from sulfide mineral decomposition in mining-impacted environments is a growing concern because of the potential for the transport of nanoscale particles that could increase the distribution of the metals and their environmental impact. An analysis of total (unfiltered) and dissolved (450-nm filtered) metal concentrations in the mining-impacted Coeur d'Alene River indicates the leaching of dissolved metal forms from sediments and transport to and within the river. The distribution of metals between total and dissolved forms is driven by seasonal temperatures, hydraulic gradients, and ligand availability. $\mathrm{Cd}$ and $\mathrm{Zn}$ were the least influenced by changes in gradient and biological productivity between the upper and lower basins. $\mathrm{Cd}$ and $\mathrm{Zn}$ primarily travel as dissolved forms, with the lowest ratio of dissolved-to-total concentrations in spring and the highest in summer. Fe and $\mathrm{Pb}$ primarily travel as suspended particles, but their dissolved forms were greater during all seasons in the lower basin. A principal components analysis of upper basin data indicates that temperature and conductivity were correlated with dissolved $\mathrm{Cd}$ and $\mathrm{Zn}$, and total $\mathrm{Fe}$ and $\mathrm{Pb}$ were correlated with streamflow. In the lower basin, dissolved $\mathrm{Cd}$ and $\mathrm{Zn}$, conductivity, and temperature were correlated, and suspended sediment, total metals, and dissolved $\mathrm{Pb}$, but not streamflow, were correlated. The correlation of metals and sediment in the lower basin is not from erosion but the availability of organic matter and Fe that form a range of dissolved to suspended metal particles. The summer decrease in surface water levels releases sediment porewater containing nanoscale-to-microscale metal particles that are transported to open water, where they may impact human and wildlife health. Such releases are unmitigated with current remediation strategies of sediment stabilization.
\end{abstract}

Keywords: metal mobility; mining-impacted sediments; biogeogenic metal nanoparticles

\section{Introduction}

The weathering of sulfide minerals may release potentially toxic metals into the environment that can continue to impact the health of human and wildlife populations for a period of decades to centuries [1-5]. The introduction of sulfide minerals to the surface environment because of mining may allow for the weathering, release, and hydrologic transport of metals such as $\mathrm{Cd}, \mathrm{Fe}, \mathrm{Pb}$, and $\mathrm{Zn}$ as inorganic and organic nano- to micro-scale particles [6,7]. The formation of transportable inorganic or organic metal nanoparticles poses substantial risks to water resources because of the potential for nanoparticles to have greater mobility, stability, and (or) bioavailability compared to free ions and (or) microparticles [8-10]. Natural metal nanoparticles have shown selective persistence and transport as 
nanophase minerals, multi-metal nanoparticles, and as nanoscale organometallic complexes in surface hydrologic systems [7,11-15].

The goal of this study was to discriminate the seasonal release and transport of dissolved $(<450 \mathrm{~nm})$ metal forms from mining-impacted sediments to surface water in the upper and lower subbasins of the Coeur d'Alene River Basin of northern Idaho. Strong seasonal changes in the biogeochemistry of mining-impacted, riverine environments may alter the formation and transport of dissolved metal forms along with larger, metal-bound suspended particles [6,7,10,12,14-17]. The remediation of mining-impacted environments is complicated by seasonal hydro-biogeochemical changes-such as the variability of temperature, sediment wetting/drying, inorganic and organic ligand availability, sorption site competition, strong and weak complexation-that influence metal mobility [11,12,14,17-23]. These dynamic, metal-rich environments include waste rock piles and contaminated sediments (e.g., impacted shallow aquifer or floodplain sediments) that may be represented as biochemical reactors that can produce porewater metal(s) reservoirs.

\section{Study Area}

The legacy impact of mining, milling, and waste rock disposal at the land surface has resulted in extensive metal contamination of natural environments such as the Coeur d'Alene River Basin of northern Idaho, USA (Figure 1). The basin is bounded by the Coeur d'Alene Mountains, which are part of the Bitterroot Range of the Northern Rocky Mountains. The Coeur d'Alene Mountains are composed of the quartzite and argillite Mesoproterozoic Belt Supergroup, which contain the ore-bearing formations that have been mined since the 1880s [24,25]. The ore primarily consists of argentiferous galena $[\mathrm{PbS}]$ and sphalerite $[(\mathrm{Zn}, \mathrm{Fe}, \mathrm{Cd}) \mathrm{S}]$ in thin $(<1-2 \mathrm{~m})$ quartz veins. Associated with the sulfidic ore are carbonate zones consisting primarily of siderite $\left[\mathrm{FeCO}_{3}\right]$ and ankerite $\left[\mathrm{Ca}(\mathrm{Fe}, \mathrm{Mg}, \mathrm{Mn})\left(\mathrm{CO}_{3}\right)_{2}\right][17,20,25]$. The mining district has processed $>130$ million tonnes of ore and produced $>7$ million tonnes of $\mathrm{Pb}, 3$ million tonnes of $\mathrm{Zn}$, and 30,000 tonnes of $\mathrm{Ag}$ [25].

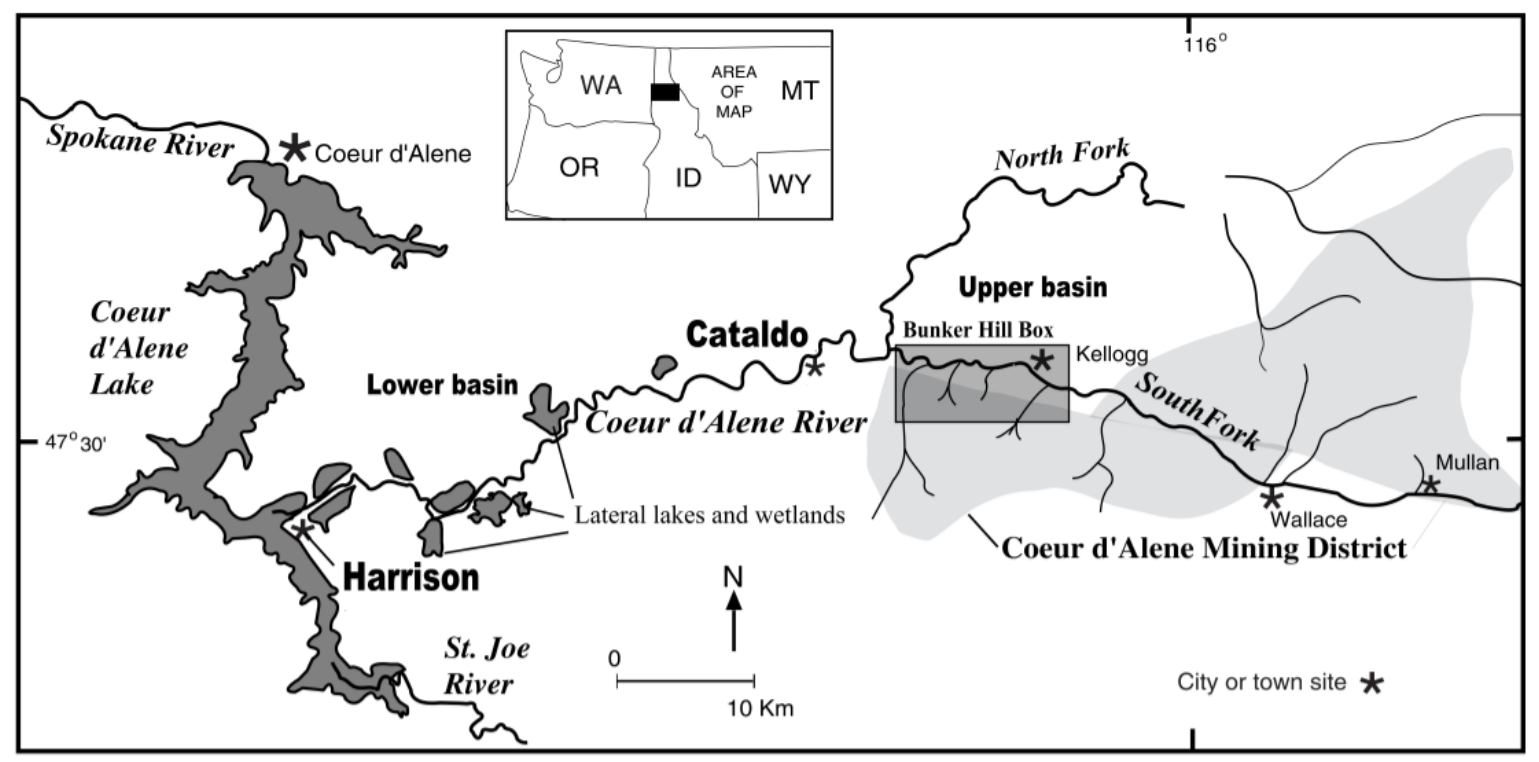

Figure 1. Upper and lower basins of the Coeur d'Alene River Basin, Idaho USA. Cataldo represents the transition point from the upper basin to the lower basin.

The Coeur d'Alene River Basin is composed of an upper, high gradient subbasin (upper basin) and the downstream, low gradient but higher biologically productive lower subbasin (lower basin) as shown in Figure 2. The basins undergo strong seasonal physicochemical changes in a northern climate where remediation efforts have struggled to limit metal loading to the surface water environment $[17,24-26]$. This area sustained considerable metal contamination because of legacy 
mining and milling practices where sulfidic waste rock was placed in unconstrained piles in the upper basin near mine adits and along the South Fork of the Coeur d'Alene River at mill sites [25-28]. The high streamflow of canyon creeks and the South Fork transported a portion of the sulfidic waste rock and metals, such as $\mathrm{Cd}, \mathrm{Fe}, \mathrm{Pb}$, and $\mathrm{Zn}$, downstream, and flood events, particularly snowmelt events, distributed these sediments across the upper basin floodplain and the lateral lake and wetland complex (lateral system) of the lower basin $[27,28]$. Superfund status was first granted in 1983 for the Bunker Hill Box (initial Superfund boundary that encompassed a major mining and milling area; Figure 1), and then expanded in 1998 to the floodplain of the upper and lower basins for future mitigation and remediation of the metal contamination present throughout the floodplain of the basin.
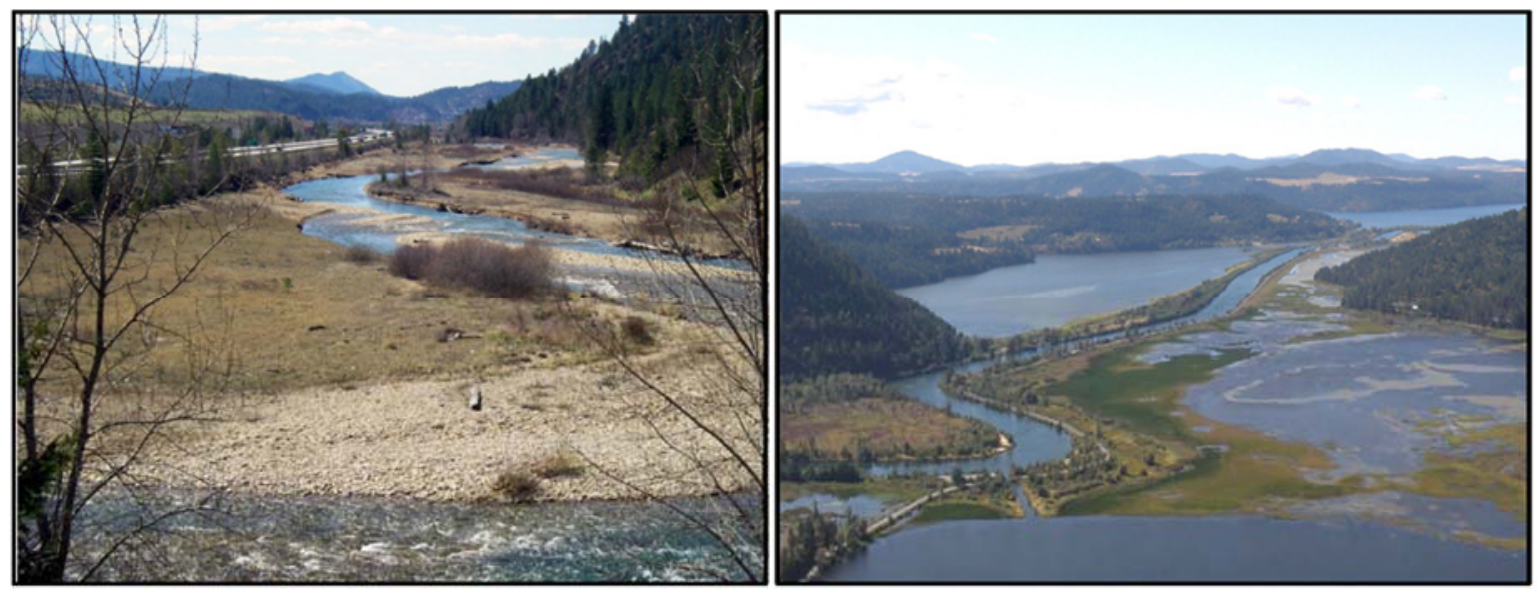

Figure 2. Images of the South Fork of the Coeur d'Alene River near Kellogg, Idaho, in the upper basin (left) and the main stem of the Coeur d'Alene River near Harrison in the lower basin (right) (courtesy of the U.S. Geological Survey).

The Coeur d'Alene River Basin can be divided at the confluence of the river's South Fork $\left(774 \mathrm{~km}^{2}\right)$ and North Fork $\left(2318 \mathrm{~km}^{2}\right)$, which merge $6 \mathrm{~km}$ upstream of the community of Cataldo, Idaho (Figure 1). The Cataldo area represents the transition to the lower basin containing the main stem of the Coeur d'Alene River, which discharges to Lake Coeur d'Alene at Harrison, Idaho (Figure 1). The steeper gradient of the upper basin produces a gravel-dominated river bed (Figure 2) with larger streamflow velocities (median of $0.6 \mathrm{~m} / \mathrm{s}$ measured by the U.S. Geological Survey (USGS) at Cataldo between 2005-2015) compared to the lower gradient of the Coeur d'Alene River in the lower basin (Figure 2; $0.15 \mathrm{~m} / \mathrm{s}$ median velocity measured by the USGS at Harrison between 2005-2015). The low velocity environment of the lower basin is exemplified by the median change in river height from Cataldo to Harrison of $3.2 \mathrm{~m}$ between 2005 and 2015, which indicates a $0.01 \%$ stream gradient over this $40 \mathrm{~km}$ distance. The slower velocity of the river and wide floodplain of the lower basin allow for extensive wetlands and lateral lakes that comprise the lateral system (Figures 1 and 2). During the summer season, the Coeur d'Alene River undergoes a transition from surface water to groundwater dominance $[13,29]$ following spring peak flows. During this hydrologic flux, seasonal changes include higher temperatures, lower water levels, and increased biological productivity, which are substantially greater in the lower basin $[20,30,31]$.

The impact of mining on land and water resources in the Coeur d'Alene River Basin is substantial in its level of contamination but not atypical for the western U.S. or other parts of the world [1,3,32,33]. It is estimated that 56 million tonnes of waste rock containing 800,000 tonnes of $\mathrm{Pb}$ and 650,000 tonnes of $\mathrm{Zn}$ were discharged into the Coeur d'Alene River and its tributaries [34]. The upper basin contains substantial remaining waste rock in the upper canyons and along the floodplain of the South Fork of the Coeur d'Alene River $[29,31,34]$. In the lower basin, sediment analyses indicate concentrations of up to $250 \mathrm{ppm} \mathrm{Cd}$ and 35,000 ppm Zn in the lateral system sediments and the substantial presence 
of $\mathrm{Zn}$ (up to $70 \mathrm{mgL}^{-1}$ ) in sediment porewater [26]. $\mathrm{Pb}$ and $\mathrm{Zn}$ have been observed to cycle between solid and aqueous phases as (oxyhydr)oxides, carbonates, and sulfides depending on biogeochemical conditions [13,35-40].

\section{Materials and Methods}

The data analyzed for this manuscript are secondary data which were collected by the U.S. Geological Survey (USGS) and made public following quality control/quality assurance reviews. The data described in this manuscript come from water samples collected by USGS personnel from 2005 to 2015 at two streamgage sites along the Coeur d'Alene River that represent the discharge from the upper basin (Coeur d'Alene River near Cataldo, Idaho (Site \#12413500; Cataldo)) and lower basin (Coeur d'Alene River near Harrison, Idaho (Site \#12413860, Harrison)). Water-quality samples were collected and analyzed according to USGS field-collection, sample-handling, and analytical protocols and USGS National Water Quality Laboratory standards as described in Clark and Mebane [31]. The samples collected from the two streamgage sites were collected concurrently-either the same day or within one day of each other. Parameters measured in the field included $\mathrm{pH}$, water temperature, and conductivity along with sample collection for the analysis of suspended sediment (total sediment mass per liter by evaporation) concentrations. Unfiltered (total or particulate + dissolved forms) and 450-nm filtered (dissolved) samples were collected for the analysis of metal concentrations by inductively coupled plasma-mass spectrometry at the USGS National Water Quality Laboratory [41,42]. Organic nitrogen $(\mathrm{N})$ was measured at both sites, and values commonly were near the method detection limit of $<0.01 \mathrm{mg} / \mathrm{L}$ (variable with matrix interference at the low concentrations). All data are publicly and freely available for secondary use through the USGS National Water Information System (NWIS) using the site identification numbers listed above (https:/ / waterdata.usgs.gov/nwis). Access to the data is described in the Supplementary Materials section. No data were listed with a value qualifier, which are used to specify unusual characteristics of the collection and measurement process that indicate a result bias and/or the magnitude of variability for the measurement.

For this study, the water-quality data were separated into seasonal periods according to changes in the river's mean annual hydrograph during 2005-2015 (Figure 3): winter (24 December to 13 March), spring (14 March to 24 June), summer (25 June to 28 October), and fall (29 October to 23 December). These periods represent changes in river hydrology according to seasonal conditions-the onset of continuous freezing temperatures (winter), snowmelt runoff (spring), low-water, low-velocity season (summer), and return of precipitation and colder temperatures (fall). The change from spring to summer represents the change from a surface-water supplied system to a groundwater-supplied system [29], which reverses the hydraulic gradient between the floodplain and river during this low water period [31]. The target periods of sampling was the spring and summer seasons, which produced variable sample sizes for each season at the Cataldo $(C)$ and Harrison $(H)$ sites: winter (C: 4, H: 18), spring (C: 11, H: 22), summer (C: 19, H: 26), fall (C: 1, H: 6).

Exploratory statistical analysis, including a principal components analysis (PCA), was performed to identify the influences on $\mathrm{Cd}, \mathrm{Fe}, \mathrm{Pb}$, and $\mathrm{Zn}$ discharging from the upper basin at Cataldo and from the lower basin at Harrison. The metals data were examined for changes in the ratio of dissolved-to-total concentrations to evaluate influences on their release and transport as potential free ions or biogeogenic nanoparticles (dissolved concentration forms) or dissolved + larger suspended forms (total concentration forms or dissolved + particulate forms). The physicochemical parameters were examined with either the dissolved or total metal concentrations to identify seasonal changes and the resulting metal concentrations and their potential form given basin characteristics and likely ligands. Nonparametric statistics were employed to determine correlation or noncorrelation between parameters because of limited sample numbers and non-normal distributions. Nonparametric statistics and curves included the Spearman rank correlation, two-tailed Wilcoxon rank sum test, and locally weighted scatterplot smoothing (LOWESS) given a 50\% fraction (smoothing parameter) for the local neighborhood. The PCA was performed on the correlation matrix because of differences in scales (e.g., 
streamflow vs. Cd concentration) and without rotation because of likely intercorrelations (e.g., Cd and Zn or streamflow and temperature).

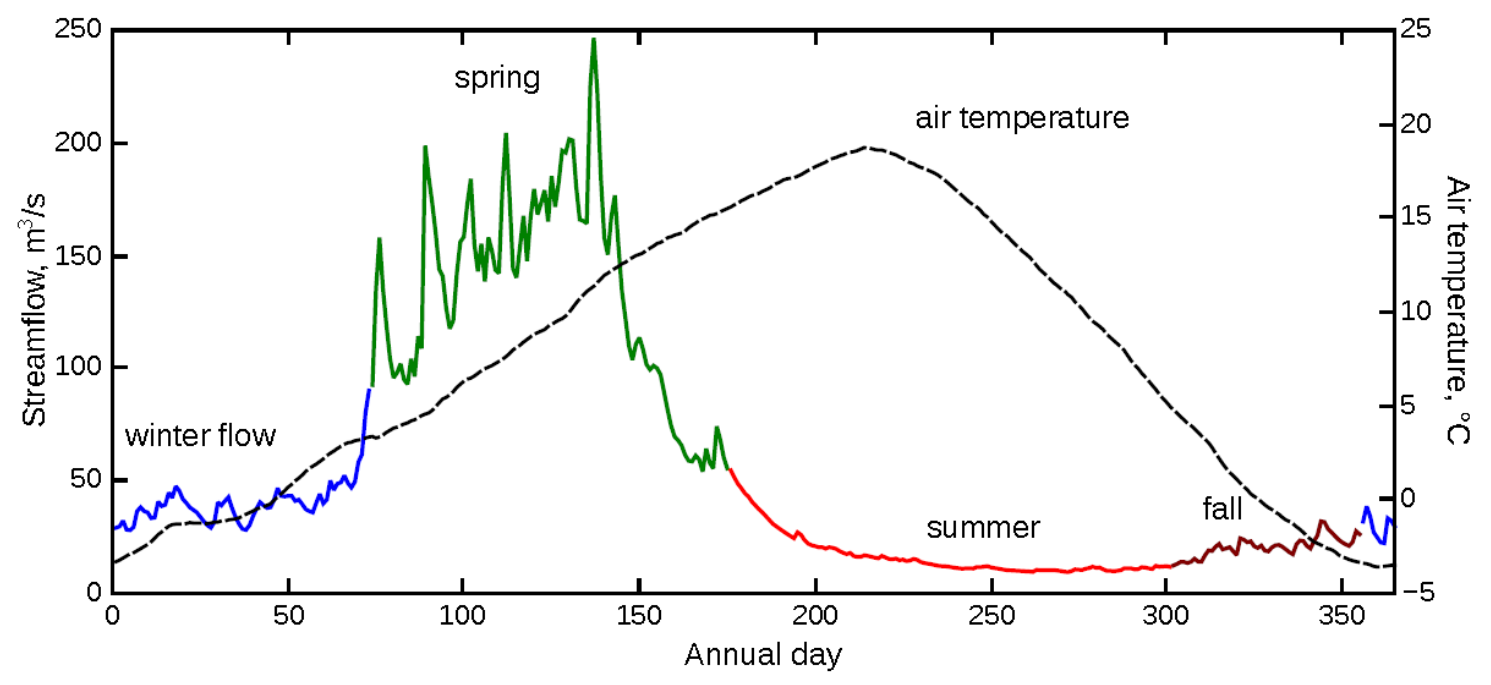

Figure 3. Median daily flow of the Coeur d'Alene River at Cataldo, Idaho, from 2005-2015 (courtesy of the U.S. Geological Survey) and median daily air temperature from 1981-2010 (courtesy of the Western Regional Climate Center). Seasonal indicators are identified according to changes in the hydrology of the river.

\section{Results}

\subsection{Physicochemical Parameters and Metal Concentrations}

The geochemical environment of the Coeur d'Alene River from Cataldo to Harrison during 2005-2015 consisted of neutral water (median pH of 6.8-7.3) with strong seasonal changes in water temperature and conductivity (Table 1). The spring runoff increased river temperatures, followed by further increases during summer (Table 1 and Figure 3). Associated with this temperature change, conductivity increased in summer for water exiting the upper and lower basins compared to the dilute streamflow (lowest median conductivity) during the spring runoff. Median suspended sediment concentrations increased during the spring runoff at both sites, then declined during summer. At Cataldo, an increase in sediment did not correlate with an increase or decrease in conductivity. This relation was linearly very weak $\left(R^{2}=0.09\right)$ and not significant (Spearman's $\rho=-0.27$, $p$ value $=0.14$ ). At Harrison, an increase in sediment produced a lower conductivity (linearly weak $\left(R^{2}=0.49\right)$ that was significant and inversely correlated (Spearman's $\rho=-0.69, p$ value $\left.\leq 0.01\right)$ ). Dissolved oxygen and redox values were unavailable for the sample sites during the study period, but the river is considered well oxygenated as it passes the Cataldo station [24].

The overall sample populations of dissolved $\mathrm{Cd}$ and $\mathrm{Zn}$ concentrations were not significantly different between basins (Table 2, full data set $p$-values of 0.57 and 0.70 ) but were significantly different in summer when concentrations declined (Table 2) from the upper to lower basins ( $p$-values of 0.00 ). Dissolved $\mathrm{Fe}$ and $\mathrm{Pb}$ (Table 2) were significantly different overall ( $p$-value of 0.00 ) and during summer ( $p$-value of 0.00) when these metal concentrations substantially increased from the upper to lower basin (Table 1). The largest $\mathrm{Cd}$ and $\mathrm{Zn}$ concentrations occurred during summer in the upper basin (missing fall data) and in fall in the lower basin. The largest dissolved Fe concentrations occurred during winter in the upper and lower basins. Dissolved $\mathrm{Pb}$ was largest during spring and summer in the upper basin and in winter in the lower basin. 
Table 1. Minimum, median, and maximum values of temperature, $\mathrm{pH}$, conductivity, and suspended sediment for water collected at the Cataldo and Harrison streamgage sites from 2005-2015.

\begin{tabular}{ccccccccccccc}
\hline & \multicolumn{3}{c}{ Temp. $\left({ }^{\circ} \mathrm{C}\right)$} & \multicolumn{3}{c}{$\mathrm{pH}$} & \multicolumn{3}{c}{ Conductivity $(\mu \mathrm{S} / \mathrm{cm})$} & \multicolumn{3}{c}{ Sus. Sediment $(\mathrm{mg} / \mathrm{L})$} \\
\hline Season & Min & Med & Max & Min & Med & Max & Min & Med & Max & Min & Med & Max \\
\hline \multicolumn{1}{c}{} & & \multicolumn{8}{c}{ Cataldo site } & (discharge from upper basin) \\
\hline Winter & 2.1 & 3.0 & 3.9 & 6.5 & 6.9 & 7.2 & 40 & 47 & 65 & 0.3 & 0.6 & 1 \\
\hline Spring & 3.3 & 5.8 & 13.9 & 6.8 & 6.9 & 7.3 & 31 & 40 & 79 & 3 & 29 & 55 \\
\hline Summer & 8.9 & 12.2 & 15.8 & 6.8 & 7.2 & 7.4 & 55 & 107 & 121 & 1 & 4 & 191 \\
\hline Fall & - & - & - & - & - & - & - & - & - & - & - & -
\end{tabular}

Harrison site (discharge from lower basin)

\begin{tabular}{ccccccccccccc}
\hline Winter & 0.6 & 3.1 & 4.4 & 5.9 & 6.8 & 7.5 & 38 & 60 & 96 & 1 & 6 & 611 \\
\hline Spring & 3.1 & 7.5 & 20.1 & 6.2 & 6.8 & 7.9 & 32 & 44 & 78 & 1 & 19 & 404 \\
\hline Summer & 8.1 & 16.1 & 23.5 & 6.8 & 7.3 & 8.2 & 56 & 93 & 111 & 1 & 3 & 12 \\
\hline Fall & 1.9 & 4.9 & 7.0 & 6.4 & 7.0 & 7.4 & 39 & 88 & 109 & 3 & 6 & 236 \\
\hline
\end{tabular}

$\mu \mathrm{S} / \mathrm{cm}$, microsiemens per centimeter; Sus., suspended; mg/L, milligrams per liter; Min; minimum; Med, median; Max, maximum.

Table 2. Median dissolved and total metal concentrations at Cataldo and Harrison and Wilcoxon rank sum test $p$-values for the overall data and seasonal data for comparison of the sample populations between basins, 2005-2015.

\begin{tabular}{|c|c|c|c|c|c|c|c|c|}
\hline Season & Diss. Cd & Total Cd & Diss. Fe & Total Fe & Diss. $\mathbf{P b}$ & Total $\mathbf{P b}$ & Diss. Zn & Total Zn \\
\hline \multicolumn{9}{|c|}{ Cataldo site (discharge from the upper basin) } \\
\hline Overall & 1.17 & 1.17 & 21.6 & 114 & 0.95 & 10.7 & $171^{*}$ & $161^{*}$ \\
\hline Winter & 0.54 & 0.96 & 29.2 & 739 & 0.79 & 40.5 & 86.8 & 113 \\
\hline Spring & 0.39 & 0.61 & 21.6 & 837 & 0.95 & 37.1 & 69.8 & 88.3 \\
\hline Summer & 1.56 & 1.55 & 19.4 & 52.6 & 0.96 & 2.92 & $291^{*}$ & $279^{*}$ \\
\hline Fall & - & - & - & - & - & - & - & - \\
\hline \multicolumn{9}{|c|}{ Harrison site (discharge from the lower basin) } \\
\hline Overall & 0.93 & 1.21 & 74.0 & 305 & 6.42 & 25.9 & 179 & 213 \\
\hline Winter & 0.93 & 1.28 & 139 & 527 & 8.91 & 32.9 & 181 & 228 \\
\hline Spring & 0.64 & 1.20 & 61.9 & 890 & 7.96 & 84.8 & 109 & 188 \\
\hline Summer & 1.05 & 1.15 & 47.5 & 196 & 3.78 & 19.4 & 194 & 195 \\
\hline Fall & 1.36 & 1.81 & 77.7 & 396 & 6.82 & 35.7 & 275 & 342 \\
\hline \multicolumn{9}{|c|}{ Wilcoxon rank sum test: $\mathrm{H}_{\mathrm{o}}$ : median difference $=0\left(\mathrm{H}_{\mathrm{a}} \neq 0\right), \alpha=0.05$} \\
\hline Overall & 0.57 & 0.16 & 0.00 & 0.00 & 0.00 & 0.00 & 0.70 & 0.01 \\
\hline Winter & ND & ND & $\mathrm{D}$ & $\mathrm{D}$ & $\mathrm{D}$ & $\mathrm{D}$ & $\mathrm{D}$ & $\mathrm{D}$ \\
\hline Spring & 0.00 & 0.01 & 0.01 & 0.34 & 0.00 & 0.10 & 0.00 & 0.00 \\
\hline Summer & 0.00 & 0.06 & 0.00 & 0.00 & 0.00 & 0.00 & 0.02 & 0.22 \\
\hline Fall & - & - & - & - & - & - & - & - \\
\hline
\end{tabular}

Diss., dissolved (filtered at $450 \mathrm{~nm}$ ); Total (unfiltered); all values are micrograms per liter; - , not available; ND, population median of differences is not different for populations containing $<10$ values at $\alpha=0.05$ ( $p$ value not available); D, population median of differences is different for populations containing $<10$ values at $\alpha=0.05$ ( $p$ value not available); $p$ value $<0.05$ indicates strong indication of difference in the median values of the sample populations; *, Zn median dissolved concentrations are larger than median total concentrations likely because of sample heterogeneity and the presence of only dissolved $\mathrm{Zn}$ in solution (no particulate-bound $\mathrm{Zn}$ to increase the total concentration). 
The dissolved-to-total concentration ratios highlight the seasonal alteration of transportable metal forms (Figure 4). During summer, $\mathrm{Cd}, \mathrm{Zn}, \mathrm{Fe}$, and $\mathrm{Pb}$ concentration ratios increased to the highest ratio for the upper basin and also for $\mathrm{Cd}$ and $\mathrm{Zn}$ in the lower basin; indicating a greater proportion of the dissolved forms being transported during this season. A greater proportion of dissolved $\mathrm{Fe}$ and $\mathrm{Pb}$ were transported in the lower basin during summer compared to spring, but this proportion did not equal the largest seasonal proportion of dissolved $\mathrm{Fe}$ and $\mathrm{Pb}$ during winter. The increased proportion of dissolved metal forms in summer at both sites (Figure 4) was preceded by the smallest ratios during the spring runoff when suspended sediment concentrations were the largest (Table 1).
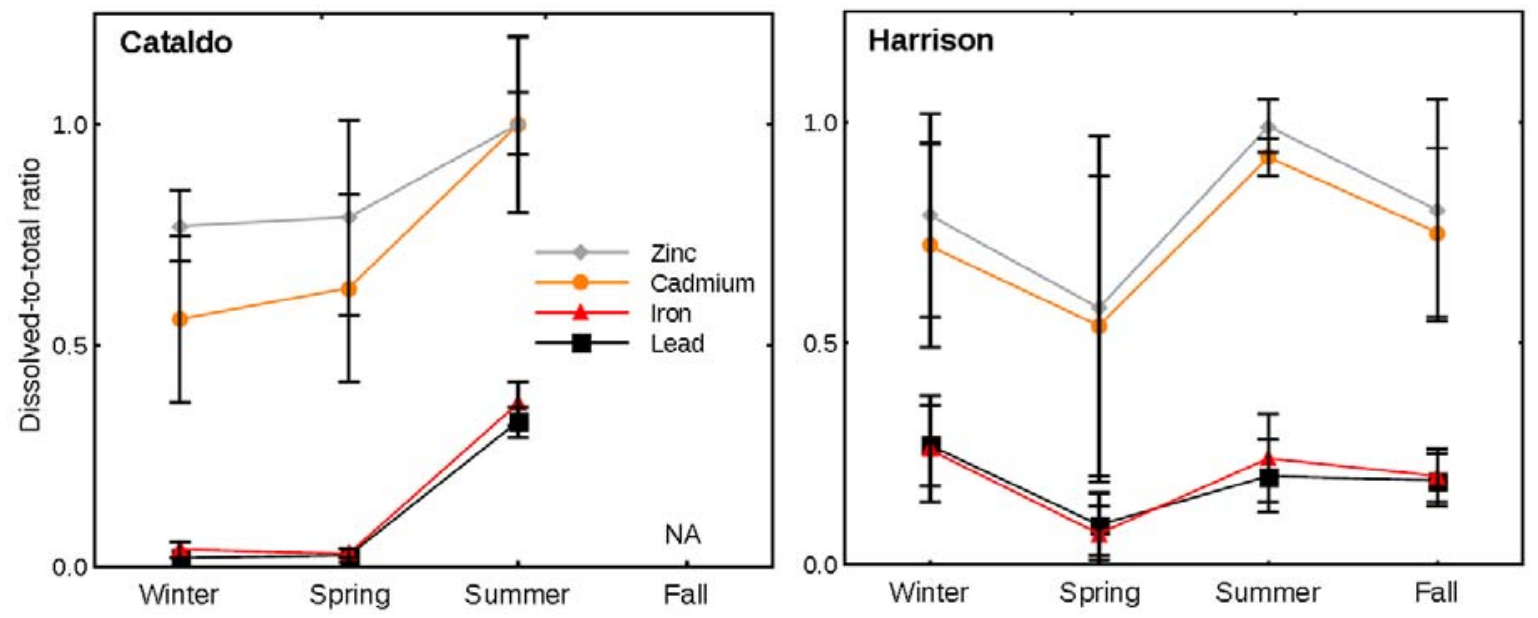

Figure 4. Median ratio and absolute deviation of dissolved-to-total concentration ratios of metals in streamflow at the Cataldo (upper basin) and Harrison (lower basin) sites, 2005-2015.

\subsection{Available Ligands and Metal Transport Relations between Basins}

The primary differences between the upper and lower basins of the Coeur d'Alene River are stream gradient and biological productivity, which produced greater suspended sediment at Cataldo (median of $5 \pm 5 \mathrm{mg} / \mathrm{L}$ ) compared to Harrison (median of $4 \pm 2 \mathrm{mg} / \mathrm{L}$ ) and lower organic $\mathrm{N}$ at Cataldo (median of $0.03 \pm 0.02 \mathrm{mg} / \mathrm{L}$ ) compared to Harrison (median of $0.11 \pm 0.07 \mathrm{mg} / \mathrm{L}$ ). Greater biological productivity in the lower basin likely increases the availability of low molecular weight organic acids that may sorb metals $[43,44]$, particularly in low velocity areas such as sediment porewater prior to discharge with changes in the hydraulic gradient. Examples of potential differences in biogeochemical environments between the basins are shown in Figures 5 and 6, where dehydrated samples collected from the basins as part of ongoing projects indicate the non-presence or presence of various organic matter (Figure 5) and the leaching of available metals from lower basin sediments during summer (Figure 6) as previously identified by Balistrieri et al. [20].

The change to a low velocity, highly productive floodplain in the lower basin appears to alter the form and transportation of metal particles, particularly $\mathrm{Pb}$-containing particles. Results of the PCA (Table 3) assist in understanding the relations between the solutes and physicochemical parameters within and between the upper and lower basins as the concentrations and parameters flux with seasonal conditions. The explanation of the variance associated with the first and second principal components was discerned (in bold) to explain a majority $(>0.5)$ of the variance (or remaining variance for the second component) of each solute as a positive or negative (inverse) correlation, as shown in Table 3. This view of each solute and the explanation of variance along a component highlights the relation of certain solutes to react, or be transported, similarly (or inversely) given the inclusion of the physicochemical parameters. The PCA results indicate a strong relationship (component 1 with $>0.5$ correlation value) of the upper basin temperature and conductivity with dissolved and total concentrations of $\mathrm{Cd}$ and $\mathrm{Zn}$ that is inversely correlated with streamflow (Table 3). Cataldo PCA 
results also indicate a positive correlation of suspended sediment and dissolved $\mathrm{Pb}$ (component 2). For total metal concentrations discharging from the upper basin, $\mathrm{Fe}$ and $\mathrm{Pb}$ are strongly correlated with streamflow but inversely correlated with temperature, conductivity, and $\mathrm{Cd}$ and $\mathrm{Zn}$. For streamflow discharging at Harrison, dissolved $\mathrm{Cd}$ and $\mathrm{Zn}$ are correlated with temperature and conductivity and inversely correlated with suspended sediment and dissolved $\mathrm{Pb}$ (Table 3). Total concentrations of $\mathrm{Cd}$, $\mathrm{Zn}, \mathrm{Fe}$, and $\mathrm{Pb}$ are correlated with suspended sediment in the lower basin and inversely correlated with conductivity (Table 3). The main change in associated solutes and physicochemical parameters is the change from correlations or inverse correlations with streamflow (upper basin) and suspended sediment (lower basin), which reflects the subbasin differences of higher gradient (more erosion) in the upper basin and higher biological productivity (more ligands and limited erosion) in the lower basin.

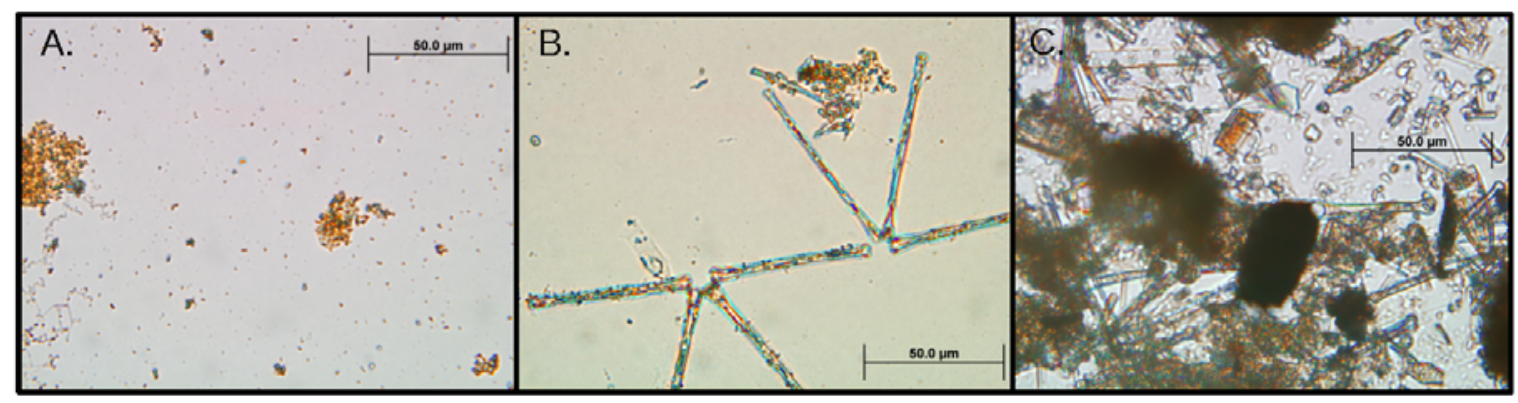

Figure 5. Potential differences in metal forms and ligands for samples from the surface and near-surface water of the upper and lower basins (dehydrated samples): (A) upper basin surface water from Burke Canyon above Wallace, Idaho, that contains primarily inorganic metal particles; (B) surface water of Thompson Lake at its outlet to the lower Coeur d'Alene River near Harrison, Idaho, that contains metal particles and filamentous algae; and (C) porewater from a sediment core collected in Thompson Lake near the outlet to the Coeur d'Alene River that contains oxidized and reduced metal particles/grains and various organic matter. All photos were captured using an SC50 Olympus digital camera on an Olympus BX51 light microscope. All images have 50- $\mu \mathrm{m}$ scale bars.

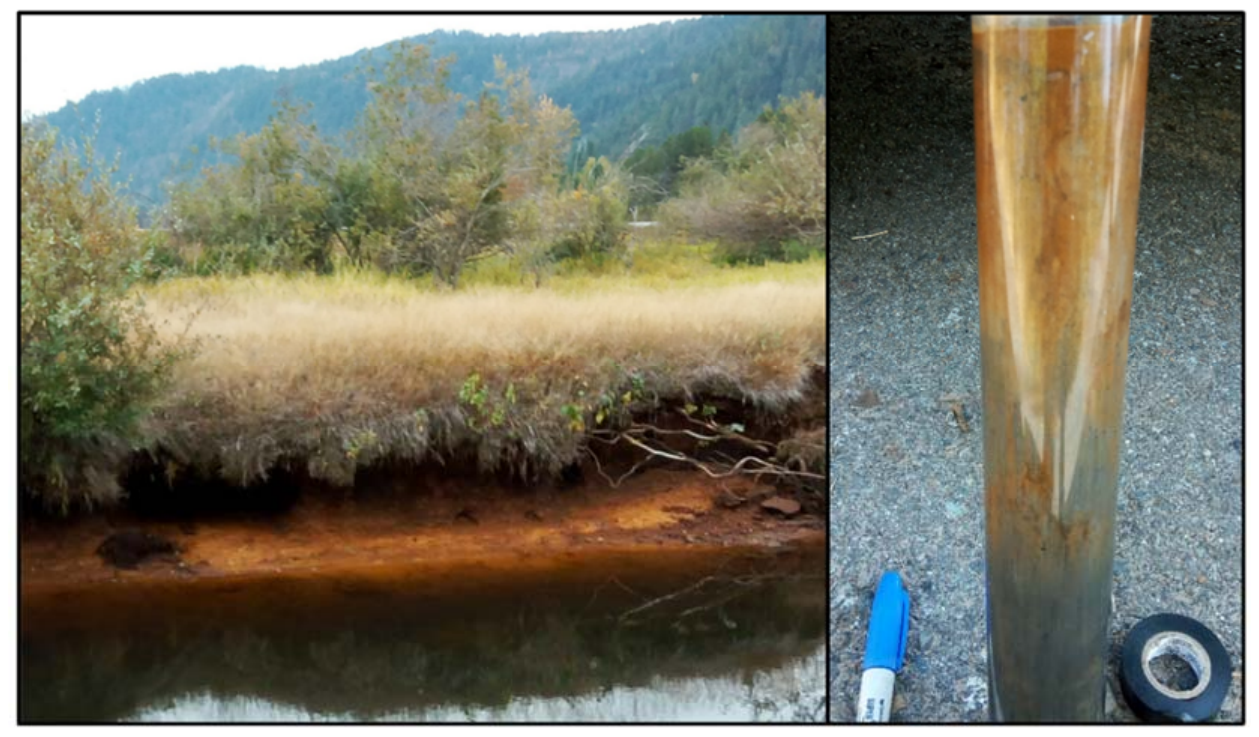

Figure 6. Images of metal-rich sediments at/from Thompson Lake in the lower basin's lateral system of the Coeur d'Alene River near Harrison. The left image is seepage of metal-rich porewater from the bank sediments following the decrease of river/lake levels during the summer season. The right image is a shallow core taken from the lake's shoreline that shows oxidized metals in the upper portion of the sediments. 
Table 3. Results of principal components analysis for dissolved and total metal concentrations and physicochemical parameters of streamflow, suspended sediment, water temperature, conductivity, and $\mathrm{pH}$.

\begin{tabular}{ccccccccc}
\hline & \multicolumn{4}{c}{ Cataldo } & \multicolumn{3}{c}{ Harrison } \\
\cline { 2 - 9 } & \multicolumn{2}{c}{ Dissolved } & \multicolumn{2}{c}{ Total } & \multicolumn{2}{c}{ Dissolved } & \multicolumn{2}{c}{ Total } \\
\hline Constituent & Comp 1 & Comp 2 & Comp 1 & Comp 2 & Comp 1 & Comp 2 & Comp 1 & Comp 2 \\
\hline \% of & & & & & & & & \\
variance & 51 & 18 & 53 & 20 & 46 & 22 & 59 & 19 \\
Streamflow & -0.88 & 0.09 & -0.91 & 0.26 & 0.48 & -0.32 & 0.37 & $\mathbf{0 . 5 8}$ \\
SS & -0.08 & $\mathbf{0 . 8 2}$ & -0.07 & -0.40 & $\mathbf{0 . 7 5}$ & -0.20 & 0.98 & -0.17 \\
Temperature & $\mathbf{0 . 8 0}$ & 0.33 & $\mathbf{0 . 7 8}$ & -0.02 & -0.57 & 0.46 & -0.43 & -0.71 \\
Conductivity & $\mathbf{0 . 9 5}$ & -0.17 & $\mathbf{0 . 9 3}$ & 0.26 & -0.85 & -0.35 & -0.53 & -0.49 \\
pH & $\mathbf{0 . 5 7}$ & 0.37 & $\mathbf{0 . 6 0}$ & -0.15 & -0.66 & 0.13 & -0.50 & -0.57 \\
Cd & $\mathbf{0 . 9 5}$ & -0.06 & $\mathbf{0 . 6 9}$ & $\mathbf{0 . 6 7}$ & -0.77 & -0.59 & $\mathbf{0 . 9 5}$ & -0.27 \\
Fe & -0.34 & -0.18 & -0.75 & $\mathbf{0 . 5 9}$ & 0.41 & -0.68 & $\mathbf{0 . 9 6}$ & -0.21 \\
Pb & -0.08 & $\mathbf{0 . 7 6}$ & -0.70 & $\mathbf{0 . 6 1}$ & $\mathbf{0 . 7 9}$ & -0.37 & $\mathbf{0 . 9 3}$ & -0.15 \\
Zn & $\mathbf{0 . 9 4}$ & -0.12 & $\mathbf{0 . 7 8}$ & $\mathbf{0 . 6 0}$ & -0.67 & -0.71 & $\mathbf{0 . 9 2}$ & -0.31 \\
\hline
\end{tabular}

all values are micrograms per liter; SS, suspended sediment; Comp, component; values are correlation values for each component (axis) - bold black and red values are those values with a correlation value $>0.5$ where the orthogonal transformation described (black) or inversely described (red) a majority of the variance in the constituents data set.

\subsection{Element Transport Differences in the Coeur d'Alene River}

$\mathrm{Cd}$ and $\mathrm{Zn}$ are typically found in natural waters, commonly as free ions or in colloidal form as singular or multi-metal nanoparticles or organometallic complexes, although $\mathrm{Zn}$ tends to be more soluble under a wider range of environmental conditions [12,14,45-50]. Balistrieri and Blank (2008) found that $\mathrm{Cd}$ and $\mathrm{Zn}$ in the dissolved phase at the Cataldo site were strongly labile (measured by diffusion gradient thin film) with a strong preference for the free ion form compared to inorganic or organic complexes. The transport of the free ion form of $\mathrm{Cd}$ and $\mathrm{Zn}$ is visible in the PCA results and exemplified in similar data trends for the dissolved-to-total concentration ratios compared to conductivity (Figure 7). For both elements, an increase to a more dissolved form (larger dissolved-to-total concentration ratio) produces greater conductivity (Figure 7) that increases as greater amounts of dissolved forms enter the river, which is indicated by increased conductivity as the concentration ratio remains near 1 (all as dissolved form). In the upper and lower basins, winter and spring produced strong variation in the dissolved-to-total concentration ratio with relatively lower conductivity as opposed to the larger concentration ratios and conductivity during summer and fall (Figure 7). Such relations indicate that the smallest $\mathrm{Cd}$ and $\mathrm{Zn}$ forms were a greater proportion of their total load during the low water period of summer and fall in the upper and lower basins.

Typically, $\mathrm{Pb}$ has low solubility in oxidizing environments where $\mathrm{Pb}^{2+}$ can sorb onto precipitating $\mathrm{Mn}$ or $\mathrm{Fe}$ (oxyhydr)oxides or form organic $\mathrm{Pb}$ colloids, and $\mathrm{Pb}$ oxides, sulfates, and carbonates have limited solubility in near-neutral to acidic environments [11,51]. Balistrieri and Blank (2008) indicate that the dissolved forms of $\mathrm{Pb}$ in the streamflow exiting the upper basin at Cataldo contained $\mathrm{Pb}$ as free ion (labile) and inorganic and organic colloidal (complexes) forms, although the free ion form is likely very small. The mixture of these transportable forms at Cataldo is visible in the $\mathrm{Pb}$ trendline for the concentration ratio vs. conductivity relation (Figure 7). The relative portion of $\mathrm{Pb}$ transported as dissolved forms increases between winter/spring and summer for the upper basin. This increase in a smaller particle form contributes to the greater conductivity of the water, similar to $\mathrm{Cd}$ and $\mathrm{Zn}$, but the majority of the transported $\mathrm{Pb}$ typically remains as larger suspended particles ( $<0.5$ dissolved-to-total ratio in Figure 7). The transition from the upper to lower basin increases the dissolved $\mathrm{Pb}$ concentrations during all seasons (Table 2), which likely is an effect of organic ligands and a strong association with $\mathrm{Fe}$ (Figure 7). This Pb-Fe relation is consistent across basins and seasons 
and is likely the transport mechanism, along with low molecular weight acids, that bind with $\mathrm{Pb}$ to form nano- to micro-scale particles in this low velocity environment.
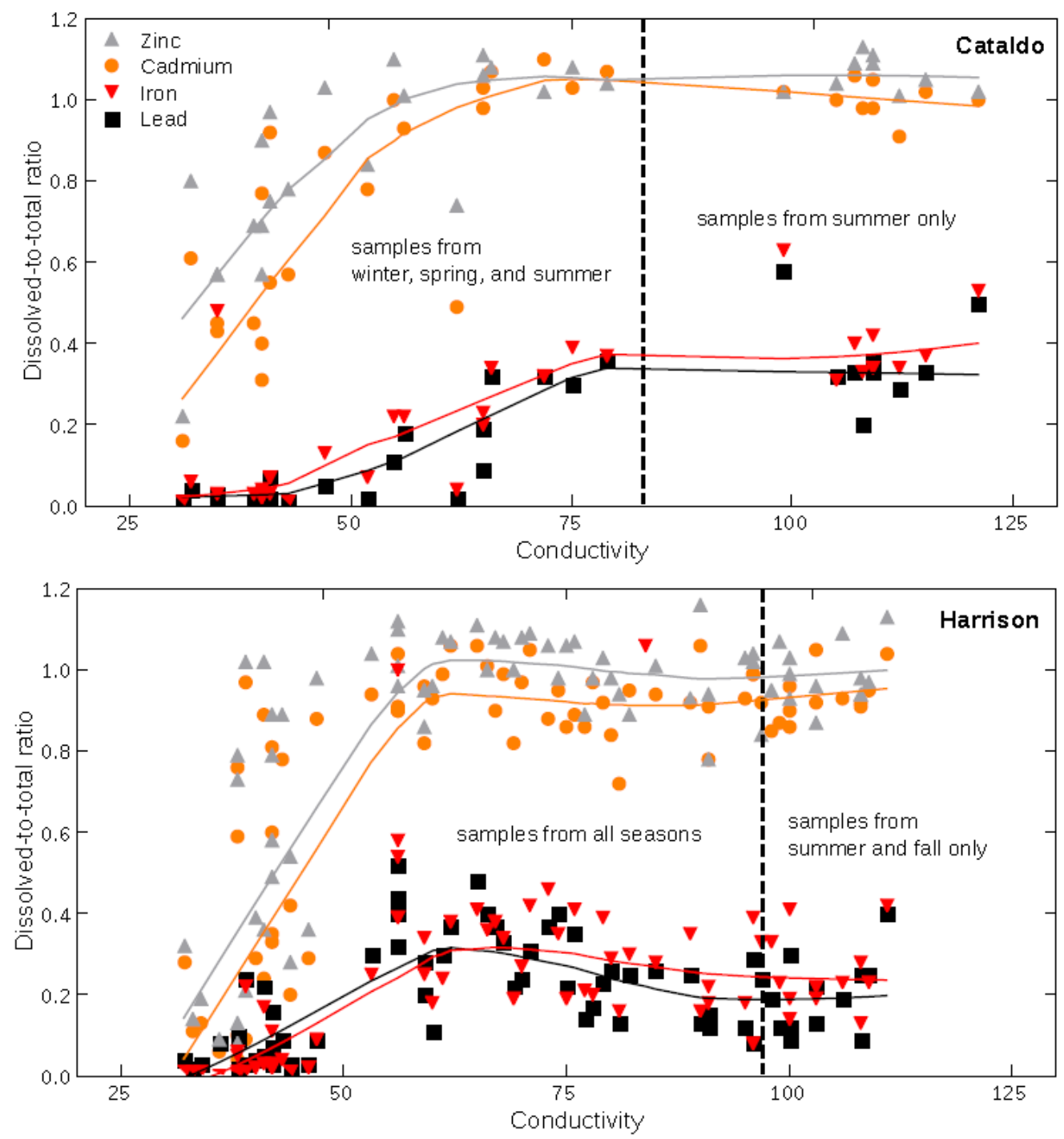

Figure 7. Relation of dissolved-to-total concentration ratios and conductivity in streamflow at the Cataldo and Harrison sites, 2005-2015. Trends are indicated by locally weighted scatterplot smoothing (LOWESS) curves given a 0.5 local neighborhood fraction.

An overview of seasonal and basinal influences on dissolved and total metal forms in the Coeur d'Alene River during 2005-2015 can be viewed in the multidimensional parallel coordinates format (Figure 8). The dissolved and total metal data were normalized to their individual range and composited to a 2D graph of parallel axes for discharge from the upper basin at Cataldo and from the lower basin at Harrison. This overview exemplifies the influence of warm temperatures (yellow and red lines compared to cold temperatures as represented by the blue lines for winter and spring) and low water period of summer that produced greater $\mathrm{pH}$ and conductivity, larger total and dissolved $\mathrm{Cd}$ and $\mathrm{Zn}$ concentrations, and smaller total and dissolved Fe concentrations in both basins (Figure 8). Additionally, the warmer temperatures and release of floodplain porewater during summer resulted in the transport of a greater proportion of dissolved $\mathrm{Pb}$ in the upper basin (Figure 8, Cataldo diss.) compared to the greater transport of dissolved $\mathrm{Fe}$ and $\mathrm{Pb}$ during colder months (blue lines) in the lower basin (Figure 8, Harrison diss.). 

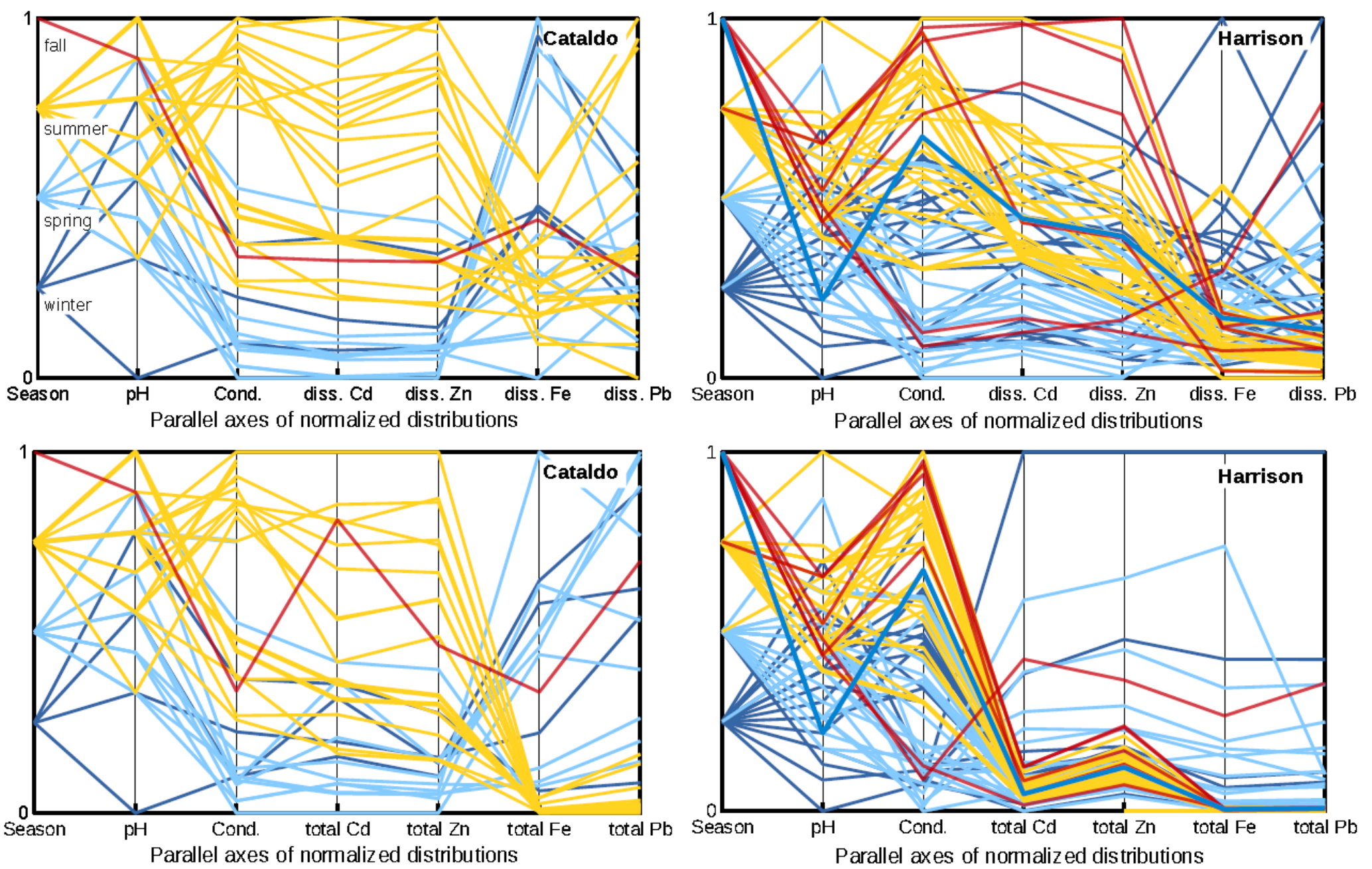

Figure 8. Parallel coordinates presentation of normalized distributions $(1=$ maximum, $0=$ minimum $)$ of the $\mathrm{pH}$ and conductivity and dissolved (diss.) and total concentration of metals by season at the Cataldo (upper basin) and Harrison (lower basin) sites on the Coeur d'Alene River. Seasonal designation by color: winter $=$ dark blue, spring $=$ light blue, summer $=$ yellow, fall $=$ red. 


\section{Discussion}

As the Coeur d'Alene River migrates through the upper and lower basins, metal and physicochemical relations are altered by seasonal and basinal changes in this mining-impacted environment. The higher gradient and lower biological productivity of the upper basin allows for greater erosion and the transport of geogenic metal forms such as free ions, multi-metal nanoparticles, or sediment-bound metals, but seasonal differences alter the ratio of dissolved to suspended metal particles. The warm temperatures of summer correspond to an increase in the dissolved phase of $\mathrm{Cd}$ and $\mathrm{Zn}$ without a corresponding increase in dissolved $\mathrm{Fe}$ and $\mathrm{Pb}$ (Tables 1 and 2). However, the largest dissolved-to-total concentration ratio of $\mathrm{Fe}$ and $\mathrm{Pb}$ occurred during summer (Figure 4), indicating likely release and transport by non-erosive actions during this low-water, low-velocity period. These changes in dissolved metal form by season in the upper basin produced a more conductive solution during summer months with the release of small particle (free ion or nanoparticle) forms. With greater $\mathrm{Cd}$ and $\mathrm{Zn}$ entering the river during the low water period and increased conductance (Figure 8), the release and transport pathway is likely a groundwater/porewater source; with a change in hydraulic gradient during the low water period that flushes dissolved metal forms from the contaminated sediments.

The summer (high temperature, low flow, and low velocity) seasonal influence on metal forms apparent in the upper basin is less apparent in the low gradient and more biologically productive lower basin, although the flow of the river through this lower basin substantially increased dissolved Fe and $\mathrm{Pb}$ concentrations (Table 2). In the lower basin, total metal concentrations were strongly correlated with suspended sediment but not correlated with streamflow because of the low velocity environment that limits erosion (Table 3). The lack of erosion and carrying capacity but larger dissolved $\mathrm{Fe}$ and $\mathrm{Pb}$ concentrations in the lower basin indicate the presence of metal-containing dissolved particles which are not generated from the physical transport associated with the higher velocity streamflow present in the upper basin where streamflow and $\mathrm{Fe}$ and $\mathrm{Pb}$ total concentrations were correlated (Table 3). Such a change from the upper basin indicates the likely production of dissolved organometallic or multi-metal nanoparticles. A wide range of organometallic and multi-metal particles are probable given the presence of fulvic and humic acids and Fe in the sediments of the heavily contaminated but biologically productive lateral system, which would produce a range of low molecular weight acids and oxides that can bind with $\mathrm{Pb}[6,9,10,14,15]$. Given the possible size range of organics acids, such as the 40-100 $\mathrm{kDa}$ that have been found bound to such metals [52], it is expected that a portion of the organometallic or geogenic $\mathrm{Fe}$ and $\mathrm{Pb}$ particles would partition below the 450-nm filter boundary. These results suggest mobilization of $\mathrm{Fe}$ and $\mathrm{Pb}$ from non-erosive actions where increased ligand availability produces transportable metal nanoparticles and microparticles likely of biogeogenic nature. This transport pathway is reflected in the lower basin's inverted sediment-conductivity relation (Spearman's $\rho=-0.69, p$ value $\leq 0.01$ ) and opposing increases in $\mathrm{Fe}$ and $\mathrm{Pb}$ but similar or slightly lower $\mathrm{Cd}$ and $\mathrm{Zn}$ concentrations between basins (Tables 2 and 3). These changes in transported Fe and $\mathrm{Pb}$ form, and the overall increase in metal loading to the riverine environment in the lower basin are a result of inputs from the metal-rich lateral system. The decline in water levels following spring allows metal-enriched, porewater inputs during summer and possibly through fall into winter.

\section{Conclusions}

The complexity of remediating mining-impacted environments requires an understanding of potential transportable metal forms and their mobility and seasonal transport pathways. Seasonal and basinal differences in climate, topography, hydrology, and biological productivity, such as those between the upper and lower basins of the mining-impacted Coeur d'Alene River Basin, alter the available source and form of metals and transport pathways, which may not be apparent to land managers. Such seasonal alterations in transportable metal forms increase the distribution and impact of the metals on the environment and the subsequent health of human and wildlife populations. The results of this study indicate a shift in metal form distribution in the Coeur d'Alene River between seasons in the upper and lower basins. A prevalent alternative idea by land managers of sediment 
entrainment and dissolution as the primary process of metal flux in the lower basin of the Coeur d'Alene River because of similar observations in the upper basin discount the large reservoir of metals in the floodplain sediments of both basins and seasonal changes in the hydro-biogeochemical environment, particularly in the biologically productive, low-velocity lower basin. The pervasion of this alternative idea as the release mechanism for metal loading limits the testing of appropriate measures to reduce metal mobility under variable hydro-biogeochemical conditions and hinders the remediation of metal loading to the wetlands, lakes, and rivers of the Coeur d'Alene River Basin. The Coeur d'Alene River Basin is a microcosm for metal remediation in a riverine environment where spatial and temporal changes in metal forms and transport pathways must be identified to properly construct appropriate remediation measures to lessen the impacts on human and wildlife populations.

Supplementary Materials: The following are available online at http://www.mdpi.com/2306-5338/5/3/35/s1. Selection of the "Water Quality" tab followed by "Historical Data" will open the "Site Selection Criteria" webpage where the site numbers (Cataldo $=12413500$; Harrison $=12413860$ ) can be entered and water-quality parameters selected for downloading/outputting in multiple data formats. Streamflow for the streamgage sites can be found from their individual site webpages on the same NWIS website.

Author Contributions: All authors conceived and designed the analysis of the existing data and analyzed the results; J.B.L. wrote the manuscript with contributions from K.T. and J.G.M. with final review by J.G.M.

Funding: This research was partially supported by U.S. National Science Foundation award \#1249400.

Acknowledgments: We acknowledge the work of the Idaho Water Resources Center of the U.S. Geological Survey; in particular, Gregory M. Clark and Christopher A. Mebane. We thank the anonymous reviewers for their thorough and thoughtful reviews which helped to improve this manuscript.

Conflicts of Interest: The authors declare no conflict of interest.

\section{References}

1. Moore, J.N.; Luoma, S.N. Hazardous wastes from large-scale metal extraction. A case study. Environ. Sci. Technol. 1990, 24, 1278-1285. [CrossRef]

2. Bigham, J.M. Mineralogy of ochre deposits formed by sulfide oxidation. In Environmental Geochemistry of Sulfide Mine-Wastes; Jambor, J.L., Blowes, D.W., Eds.; Mineralogical Association of Canada: Québec, QC, Canada, 1994; Volume 22, pp. 103-132, ISBN 978-0-8412-2772-9.

3. Dudka, S.; Adriano, D.C. Environmental impacts of metal ore mining and processing: A review. J. Environ. Qual. 1997, 26, 590-602. [CrossRef]

4. Bigham, J.M.; Nordstrom, D.K. Iron and aluminum hydroxysulfates from acid sulfate water. In Sulfate Minerals: Crystallography, Geochemistry, and Environmental Significance; Alpers, C.N., Ed.; Reviews in Mineralogy; Mineralogical Society of America: Chantilly, VA, USA, 2000; Volume 40, pp. 351-403.

5. Pyatt, F.B.; Grattan, J.P. Some consequences of ancient mining activities on the health of ancient and modern human populations. J. Public Health 2001, 23, 235-236. [CrossRef]

6. Wigginton, N.S.; Haus, K.L.; Hochella, M.F., Jr. Aquatic environmental nanoparticles. J. Environ. Monit. 2007, 9, 1306-1316. [CrossRef] [PubMed]

7. Hochella, M.F., Jr.; Lower, S.K.; Maurice, P.A.; Penn, R.L.; Sahai, N.; Sparks, D.L.; Twining, B.S. Nanominerals, mineral nanoparticles, and Earth systems. Science 2008, 319, 1631-1635. [CrossRef] [PubMed]

8. Ju-Nam, Y.; Lead, J.R. Manufactured nanoparticles: An overview of their chemistry, interactions and potential environmental implications. Sci. Total Environ. 2008, 400, 396-414. [CrossRef] [PubMed]

9. Keller, A.A.; Wang, H.; Zhou, D.; Lenihan, H.S.; Cherr, G.; Cardinale, B.J.; Miller, R.; Ji, Z. Stability and aggregation of metal oxide nanoparticles in natural aqueous matrices. Environ. Sci. Technol. 2010, 44, 1962-1967. [CrossRef] [PubMed]

10. Delay, M.; Frimmel, F.H. Nanoparticles in aquatic systems. Anal. Bioanal. Chem. 2011, 402, 583-592. [CrossRef] [PubMed]

11. Kretzschmar, R.; Schäfer, T. Metal retention and transport on colloidal particles in the environment. Elements 2005, 1, 205-210. [CrossRef]

12. Hoffmann, S.R.; Shafer, M.M.; Armstrong, D.E. Strong colloidal and dissolved organic ligands binding copper and zinc in rivers. Environ. Sci. Technol. 2007, 41, 6996-7002. [CrossRef] [PubMed] 
13. Haus, K.L.; Hooper, R.L.; Strumness, L.A.; Mahoney, J.B. Analysis of arsenic speciation in mine contaminated lacustrine sediment using selective sequential extraction, HR-ICPMS and TEM. Appl. Geochem. 2008, 23, 692-704. [CrossRef]

14. Aiken, G.R.; Hsu-Kim, H.; Ryan, J.N. Influence of dissolved organic matter on the environmental fate of metals, nanoparticles, and colloids. Environ. Sci. Technol. 2011, 45, 3196-3201. [CrossRef] [PubMed]

15. Plathe, K.L.; von der Kammer, F.; Hassellöv, M.; Moore, J.N.; Murayama, M.; Hofmann, T.; Hochella, M.F., Jr. The role of nanominerals and mineral nanoparticles in the transport of toxic trace metals: Field-flow fractionation and analytical TEM analyses after nanoparticle isolation and density separation. Geochim. Cosmochim. Acta 2013, 102, 213-225. [CrossRef]

16. Hochella, M.F., Jr.; Moore, J.N.; Putnis, C.V.; Putnis, A.; Kasama, T.; Eberl, D.D. Direct observation of heavy metal-mineral association from the Clark Fork River Superfund Complex: Implications for metal transport and bioavailability. Geochim. Cosmochim. Acta 2005, 69, 1651-1663. [CrossRef]

17. Balistrieri, L.S.; Blank, R.G. Dissolved and labile concentrations of $\mathrm{Cd}, \mathrm{Cu}, \mathrm{Pb}$, and $\mathrm{Zn}$ in the South Fork Coeur d'Alene River, Idaho: Comparisons among chemical equilibrium models and implications for biotic ligand models. Appl. Geochem. 2008, 23, 3355-3371. [CrossRef]

18. Cornell, R.M. Simultaneous incorporation of $\mathrm{Mn}, \mathrm{Ni}$ and $\mathrm{Co}$ in the goethite (alpha-FeOOH) structure. Clay Miner. 1991, 26, 427-430. [CrossRef]

19. Galán, E.; Gómez-Ariza, J.L.; González, I.; Fernández-Caliani, J.C.; Morales, E.; Giráldez, I. Heavy metal partitioning in river sediments severely polluted by acid mine drainage in the Iberian Pyrite Belt. Appl. Geochem. 2003, 18, 409-421. [CrossRef]

20. Balistrieri, L.S.; Box, S.E.; Tonkin, J.W. Modeling precipitation and sorption of elements during mixing of river water and porewater in the Coeur d'Alene River Basin. Environ. Sci. Technol. 2003, 37, 4694-4701. [CrossRef] [PubMed]

21. Gao, Y.; Kan, A.T.; Tomson, M.B. Critical evaluation of desorption phenomena of heavy metals from natural sediments. Environ. Sci. Technol. 2003, 37, 5566-5573. [CrossRef] [PubMed]

22. Boujelben, N.; Bouzid, J.; Elouear, Z. Adsorption of nickel and copper onto natural iron oxide-coated sand from aqueous solutions: Study in single and binary systems. J. Hazard. Mater. 2009, 163, 376-382. [CrossRef] [PubMed]

23. Stolpe, B.; Guo, L.; Shiller, A.M.; Aiken, G.R. Abundance, size distributions and trace-element binding of organic and iron-rich nanocolloids in Alaskan rivers, as revealed by field-flow fractionation and ICP-MS. Geochim. Cosmochim. Acta 2013, 105, 221-239. [CrossRef]

24. Paulson, A.J. Biogeochemical removal of $\mathrm{Zn}$ and $\mathrm{Cd}$ in the Coeur d'Alene River (Idaho, USA), downstream of a mining district. Sci. Total Environ. 2001, 278, 31-44. [CrossRef]

25. National Research Council. Superfund and Mining Megasites: Lessons from the Coeur d'Alene River Basin; U.S. Environmental Protection Agency: Washington, DC, USA, 2005; p. 484.

26. Balistrieri, L.S.; Box, S.E.; Bookstrom, A.A.; Hooper, R.L.; Mahoney, J.B. Impacts of Historical Mining in the Coeur d'Alene River Basin; Bulletin 2191-6; U.S. Geological Survey: Reston, VA, USA, 2010.

27. Reece, D.E.; Felkey, J.R.; Wai, C.M. Heavy metal pollution in the sediments of the Coeur d'Alene River, Idaho. Environ. Geol. 1978, 2, 289-293. [CrossRef]

28. Sprenke, K.F.; Rember, W.C.; Bender, S.F.; Hoffmann, M.L.; Rabbi, F.; Chamberlain, V.E. Toxic metal contamination in the lateral lakes of the Coeur d'Alene River valley, Idaho. Environ. Geol. 2000, 39, 575-586. [CrossRef]

29. Barton, G.J. Dissolved Cadmium, Zinc, and Lead Loads from Ground-Water Seepage into the South Fork Coeur d'Alene River System, Northern Idaho, 1999; Water-Resources Investigations Report 2001-4274; U.S. Geological Survey: Reston, VA, USA, 2002; p. 134.

30. Hickey, P.J.; McDaniel, P.A.; Strawn, D.G. Characterization of iron- and manganese-cemented redoximorphic aggregates in wetland soils contaminated with mine wastes. J. Environ. Qual. 2008, 37, 2375-2385. [CrossRef] [PubMed]

31. Clark, G.M.; Mebane, C.A. Sources, Transport, and Trends for Selected Trace Metals and Nutrients in the Coeur d'Alene and Spokane River Basins, Northern Idaho, 1990-2013; Scientific Investigations Report 2014-5204; U.S. Geological Survey: Reston, VA, USA, 2014; p. 62.

32. Egiebor, N.O.; Oni, B. Acid rock drainage formation and treatment: A review. Asia-Pac. J. Chem. Eng. 2007, 2, 47-62. [CrossRef] 
33. Nordstrom, D.K. Sulfide mineral oxidation. In Encyclopedia of Geobiology; Reitner, J., Thiel, V., Eds.; Encyclopedia of Earth Sciences Series; Springer: Dordrecht, The Netherlands, 2011; pp. 856-858. ISBN 978-1-4020-9211-4.

34. Bookstrom, A.A.; Box, S.E.; Campbell, J.K.; Foster, K.I.; Jackson, B.L. Lead-Rich Sediments, Coeur d'Alene River Valley, Idaho: Area, Volume, Tonnage, and Lead Content; Open File Report 2001-140; U.S. Geological Survey: Reston, VA, USA, 2001.

35. Horowitz, A.J.; Elrick, K.A.; Cook, R.B. Effect of mining and related activities on the sediment trace element geochemistry of Lake Coeur d'Alene, Idaho, USA. Part I: Surface sediments. Hydrol. Process. 1993, 7, 403-423. [CrossRef]

36. Harrington, J.M.; LaForce, M.J.; Rember, W.C.; Fendorf, S.E.; Rosenzweig, R.F. Phase associations and mobilization of iron and trace elements in Coeur d'Alene Lake, Idaho. Environ. Sci. Technol. 1998, 32, 650-656. [CrossRef]

37. Bostick, B.C.; Hansel, C.M.; Fendorf, S. Seasonal Fluctuations in Zinc Speciation within a Contaminated Wetland. Environ. Sci. Technol. 2001, 35, 3823-3829. [CrossRef] [PubMed]

38. Kuwabara, J.S.; Woods, P.F.; Berelson, W.M.; Balistrieri, L.S.; Carter, J.L.; Topping, B.R.; Fend, S.V. Importance of Sediment-Water Interactions in Coeur d'Alene Lake, Idaho, USA: Management Implications. Environ. Manag. 2003, 32, 348-359. [CrossRef]

39. Moberly, J.G.; Borch, T.; Sani, R.K.; Spycher, N.F.; Şengör, S.S.; Ginn, T.R.; Peyton, B.M. Heavy metal-mineral associations in Coeur d'Alene River sediments: A synchrotron-based analysis. Water Air Soil Pollut. 2008, 201, 195-208. [CrossRef]

40. Moberly, J.; D'Imperio, S.; Parker, A.; Peyton, B. Microbial community signature in Lake Coeur d'Alene: Association of environmental variables and toxic heavy metal phases. Appl. Geochem. 2016, 66, 174-183. [CrossRef]

41. Garbarino, J.R.; Struzeski, T.M. Methods of analysis by the U.S. Geological Survey National Water Quality Laboratory-Determination of Elements in Whole-Water Digests Using Inductively Coupled Plasma-Optical Emission Spectrometry and Inductively Coupled Plasma-Mass Spectrometry; Open-File Report 98-165; U.S. Geological Survey: Reston, VA, USA, 1998.

42. Garbarino, J.R. Methods of Analysis by the U.S. Geological Survey National Water Quality Laboratory—Determination of Dissolved Arsenic, Boron, Lithium, Selenium, Strontium, Thallium, and Vanadium Using Inductively Coupled Plasma-Mass Spectrometry; Open File Report 99-094; U.S. Geological Survey: Reston, VA, USA, 1999.

43. Tuschall, J.R.; Brezonik, P.L. Characterization of organic nitrogen in natural waters: Its molecular size, protein content, and interactions with heavy metals. Limnol. Oceanogr. 1980, 25, 495-504. [CrossRef]

44. Manceau, A.; Matynia, A. The nature of $\mathrm{Cu}$ bonding to natural organic matter. Geochim. Cosmochim. Acta 2010, 74, 2556-2580. [CrossRef]

45. Hem, J.D. Chemistry and occurrence of cadmium and zinc in surface water and groundwater. Water Resour. Res. 1972, 8, 661-679. [CrossRef]

46. Bruemmer, G.W.; Gerth, J.; Tiller, K.G. Reaction kinetics of the adsorption and desorption of nickel, zinc and cadmium by goethite. I. Adsorption and diffusion of metals. J. Soil Sci. 1988, 39, 37-52. [CrossRef]

47. Krishnamurthy, S. Biomethylation and environmental transport of metals. J. Chem. Educ. 1992, 69, 347. [CrossRef]

48. Benoit, G.; Rozan, T.F. The influence of size distribution on the particle concentration effect and trace metal partitioning in rivers. Geochim. Cosmochim. Acta 1999, 63, 113-127. [CrossRef]

49. Adriano, D.C. Trace Elements in Terrestrial Environments; Springer: New York, NY, USA, 2001; ISBN 978-1-4684-9505-8.

50. Zhang, X.; Sun, H.; Zhang, Z.; Niu, Q.; Chen, Y.; Crittenden, J.C. Enhanced bioaccumulation of cadmium in carp in the presence of titanium dioxide nanoparticles. Chemosphere 2007, 67, 160-166. [CrossRef] [PubMed] 
51. Traina, S.J.; Laperche, V. Contaminant bioavailability in soils, sediments, and aquatic environments. Proc. Natl. Acad. Sci. USA 1999, 96, 3365-3371. [CrossRef] [PubMed]

52. Kozyatnyk, I.; Bouchet, S.; Björn, E.; Haglund, P. Fractionation and size-distribution of metal and metalloid contaminants in a polluted groundwater rich in dissolved organic matter. J. Hazard. Mater. 2016, 318, 194-202. [CrossRef] [PubMed] 